\title{
ENVIRONMENTAL ASSESSMENT OF MICROALGAE BIODIESEL PRODUCTION IN COLOMBIA: COMPARISON OF THREE OIL EXTRACTION SYSTEMS
}

\author{
EVALUACIÓN AMBIENTAL DE LA PRODUCCIÓN DE BIODIESEL \\ DE MICROALGAS EN COLOMBIA: COMPARACIÓN DE TRES SISTEMAS \\ DE EXTRACCIÓN DE ACEITE
}

Yeniffer Pardo-Cárdenas ${ }^{1 *}$, Israel Herrera-Orozco ${ }^{3}$, Ángel-Darío González-Delgado ${ }^{1,2}$ and Viatcheslav Kafarov ${ }^{1}$

\author{
'Universidad Industrial de Santander, Bucaramanga, Santander, Colombia \\ ${ }^{2}$ Universidad de San Buenaventura, Cartagena, Bolivar, Colombia \\ ${ }^{3}$ Centro de Investigaciones Energéticas, Medio Ambientales y Tecnológicas, Madrid, España
}

e-mail: yenniferpardo@gmail.com

\section{ABSTRACT}

(Received: Jul. 24, 2012; Accepted: Apr. 23, 2013)

he objective of the study was to compare three cases of biodiesel production from microalgae dried
biomass applying the Life Cycle Assessment (LCA) technique by means of the "cradle to grave" concept,
presenting preliminary results for environmental assessment of emerging technologies for microalgae
biodiesel production in Colombia focused on oil extraction stage. The evaluated processes correspond to the
following cases: case 1 hexane-based extraction (HE), case 2 methanol/chloroform (MCE) and case 3 ethanol/
hexane (EHE). Operating conditions for each extraction method were adjusted with experimental work. Routes were
simulated using the Aspen Plus ${ }^{\circledR} 7.1$ software, taking as a feedstock a robust modeled composition of Chlorella
sp. Environmental emissions associated with algae biodiesel production were quantified and evaluated through
the Simapro 7.1 software. The outcomes confirm the potential of microalgae as a sink of greenhouses gases, but
highlight the crucial necessity of decreasing energy consumption and some technical improvements in oil extraction
step. Results related with greenhouse gas (GHG) emissions were compared with European sustainability criteria, in
order to identify the reduction of the hypothetical microalgae biodiesel. Case 1 presents the most important reduc-
tion respect to fossil reference ( $156 \%$ ). For the other two scenarios, reduction decreases because of higher energy
consumption. Case 2 presents a reduction of approximately $99 \%$ and case 3 presents a reduction reaching $14 \%$.

Keywords: Biodiesel, Life cycle, Microalgae, Biomass, Analysis, Process simulation.

How to cite: Pardo-Cárdenas, Y., Herrera-Orozco, I., González-Delgado, A. D. \& Kafarov, V. (2013). Environmental assessment of microalgae biodiesel production in Colombia: Comparison of three oil extraction systems. CT\&F - Ciencia, Tecnología y Futuro, 5(2), 85-100.

*To whom correspondence should be addressed

+V Congreso Internacional de Ciencia y Tecnología de los Biocombustibles, CIBSCOL 2012, Universidad Industrial de Santander, Bucaramanga, Santander, Colombia. 5 - 8 de junio de 2012. 


\section{RESUMEN}

$\mathrm{E}$

I objetivo del estudio fue comparar tres casos de producción de biodiesel de microalgas en Colombia basados en tecnologías emergentes para la extracción de aceite aplicando la técnica de Análisis de Ciclo de Vida (ACV) mediante el concepto "cuna a tumba". Los métodos evaluados corresponden a los tres casos comparados: caso 1, extracción por hexano (HE); caso 2, extracción con metanol/cloroformo (MCE), y caso 3, etanol/hexano (EHE). Las condiciones de operación para cada método fueron previamente ajustadas experimentalmente. Las rutas fueron simuladas usando el software Aspen Plus ${ }^{\circledR} 7.1$, tomando como materia prima un robusto modelo de la microalga Chlorella sp. Las emisiones ambientales asociadas con la producción de biodiesel fueron cuantificadas y evaluadas utilizando el software Simapro 7. 1. Los resultados confirman el potencial de las microalgas como sumideros de gases de efecto invernadero, pero resaltan la necesidad de disminuir el consumo de energía y de hacer algunas mejoras técnicas en la etapa de extracción de aceite. Los resultados relacionados con las emisiones de Gases de Efecto Invernadero (GEI) se compararon con los criterios europeos de sostenibilidad. El caso 1 presenta la reducción más importante respecto a la referencia fósil (156\%). En los otros dos casos, la reducción disminuye a causa del elevado consumo de energía, el caso 2 presenta una reducción del $99 \%$ y el caso 3 del $14 \%$.

Palabras clave: Biodiesel, Ciclo de Vida, Microalgas, Biomasa, Análisis, Simulación de procesos.

\section{RESUMO}

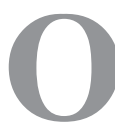

objetivo do estudo foi comparar três casos de produção de biodiesel de microalgas na Colômbia baseados em tecnologias emergentes para a extração de óleo aplicando a técnica de Análise de Ciclo de Vida (ACV) mediante o conceito "berço ao túmulo". Os métodos avaliados correspondem aos três casos comparados: caso 1, extração por hexano (HE); caso 2, extração com metanol/clorofórmio (MCE) e; caso 3, etanol/hexano (EHE). As condições de operação para cada método foram previamente ajustadas experimentalmente. As rotas foram simuladas usando o software Aspen Plus ${ }^{\circledR}$ 7.1, tomando como matéria-prima um robusto modelo da microalga Chlorella sp. As emissões ambientais associadas com a produção de biodiesel foram quantificadas e avaliadas utilizando o software Simapro 7.1. Os resultados confirmam o potencial das microalgas como sumidouros de gases de efeito estufa, mas ressaltam a necessidade de diminuir o consumo de energia e de fazer algumas melhoras técnicas na etapa de extração de óleo. Os resultados relacionados com as emissões de Gases de Efeito Estufa (GEI) são comparados com os critérios europeus de sustentabilidade. $\bigcirc$ caso 1 apresenta a redução mais importante com relação à referência fóssil (156\%). Nos outros dois casos, a redução diminui por causa do elevado consumo de energia, o caso 2 apresenta uma redução de $99 \%$ e o caso 3 de $14 \%$.

Palavras-chave: Biodiesel, Ciclo de Vida, Microalgas, Biomassa, Análise, Simulação de processos. 


\section{INTRODUCTION}

Microalgae seem to be an attractive way to produce biofuels due to their ability to accumulate lipids and their very high photosynthetic yields; about $3-8 \%$ of solar energy can be converted to biomass whereas observed yields for terrestrial plants are about $0.5 \%$ (Huntley \& Redalje 2007; Li et al., 2008). The current algal biofuels program at the National Renewable Energy Laboratory (NREL) builds on expertise and knowledge acquired during the Aquatic Species Program, a U.S. Department of Energy (DOE) funded research effort established in 1978, specifically investigating microalgae biofuels. The program was disbanded, but with the recent rise in energy prices and concern about climate change and carbon emissions, there is a renewed interest in algae-based biofuels.

Production costs of biodiesel from microalgae are even higher when compared to conventional fuels. There are few studies about it due to the novelty of the process; however, biodiesel production costs exhibit economies of scale. All stages involved in microalgae biodiesel production chain require high energy, thus contributing to high production costs. Table 1 shows a comparison of microalgae with other raw materials to be used as biodiesel source (González \& Kafarov, 2011).

Current studies show that production of microalgae is too expensive for biodiesel use alone; this is another reason to conduct microalgae research in the biorefineries field. The International Energy Agency defines biorefining as biomass processing in a sustainable manner within a spectrum of marketable products and energy. This concept can be extended, according to Cherubini (2010), to a laboratory or a set of laboratories that integrates biomass transformation processes and equipment for the production offuels for transportation, energy and chemicals.

In terms of biorefinery, microalgae are a promissory feedstock because of its capability to obtain biofuels and high value products. Efficiency of microalgae oil extraction contributes in a great way to the total biomass transformation efficiency process. For this reason, sustainable microalgae based biorefineries must take into account different aspects related to lipids separation.

A wide variety of organic solvents are often used to extract oil from microalgae, where hexane and ethanol are the most common. However, ethanol is a polar solvent and its selectivity to lipids is relatively low compared to other solvents, so in extractions with ethanol, other microalgae components may also appear, such as sugars, pigments or amino acids. Using a hexane-ethanol mixture, approximately $80 \%$ of fatty acids present in biomass can be extracted (Fajardo et al., 2007). Solvent based lipid extraction methods such as Bligh \& Dyer's method, which uses a methanol chloroform mixture, have been tested successfully in oil extraction from microalgae (Bligh \& Dyer, 1959). However, this method is not environmentally friendly due to the toxicity of the solvents used; others present the disadvantage of high volatility, increasing solvent loss at long extraction times. Hexane is frequently used for soxhlet extraction using microalgae biomass as a raw material (Gao, Zhai, Ding \& Wu, 2010). Hexane is cheaper than other non-polar solvents such as cyclohexane, it is easy-to-recover after extraction and is selective to neutral lipids. In addition, it can be used in mixture with isopropanol (Halim, Gladman, Danquah \&

Table 1. Comparison of some sources of biodiesel (González \& Kafarov, 2011).

\begin{tabular}{|c|c|c|c|c|c|c|c|}
\hline $\begin{array}{l}\text { Raw } \\
\text { Material }\end{array}$ & $\begin{array}{l}\text { Oil Content } \\
\text { (\% in Dry } \\
\text { Weight } \\
\text { Biomass) }\end{array}$ & $\begin{array}{l}\text { Output } \\
\text { (L oil/ha } \\
\text { year) }\end{array}$ & $\begin{array}{c}\text { Land Used } \\
\left(\mathrm{m}^{2} \text { year } / \mathrm{kg} \text { Biodiesel) }\right.\end{array}$ & $\begin{array}{l}\text { Water Footprint } \\
\qquad\left(\mathrm{m}^{3} / \text { ton }\right)\end{array}$ & $\begin{array}{l}\text { Production } \\
\text { Cost (US\$/L) }\end{array}$ & $\begin{array}{l}\text { Acid Value } \\
\text { of Oil }\end{array}$ & $\begin{array}{l}\text { Biodiesel } \\
\text { Yield (\%) }\end{array}$ \\
\hline Soybeans & 18 & 636 & 18 & 4200 & $0.40-0.60$ & 0.2 & 90 \\
\hline Rapeseed & 41 & 974 & 12 & 4300 & 0.99 & 2.0 & 87 \\
\hline Sunflower & 40 & 1070 & 11 & 6800 & 0.62 & 0.1 & 90 \\
\hline Oil Palm & 36 & 5366 & 2 & 5000 & 0.68 & 6.1 & 95 \\
\hline Castor & 48 & 1307 & 9 & 24700 & $0.92-1.56$ & 4.6 & 89 \\
\hline Microalgae* & 50 & 97800 & 0.1 & $591-3276$ & $3.96-10.56$ & 8.9 & 60 \\
\hline
\end{tabular}

* Medium oil content, cultured in photobioreactors 
Webley, 2011), which is considered safe in an industrial scale, being used for lipid extraction from soybean.

The structural characteristic of biodiesel determines that biodiesel is a feasible substitute for conventional energy (GuanHua et al., 2010). The viscosities of vegetable oils and microalgae oils are usually higher than those of diesel oils (Fuls, Hawkins \& Hugo, 1984). However, they cannot be applied to engines directly to assess the potential of biodiesel as a substitute of diesel fuel (Miao \& Wu, 2006); determining the values of the properties of biodiesel such as density, viscosity, flash point, cold filter plugging point, solidifying point and heating. Table 2 shows a comparison of these properties of diesel fuel (Ma \& Hanna 1999; Lang et al., 2001; Al-Widyan \& Al-Shyoukh, 2002; Antolín et al., 2002; Vicente, Martínez \& Aracil, 2004) and biodiesel from microalgae oil and ASTM biodiesel standard. Most of these parameters comply with the limits established by ASTM related to biodiesel quality (Antolin et al., 2002). The physical and fuel properties of biodiesel from microalgae oil in general were comparable to those of diesel fuel. The biodiesel from microalgae oil showed a much lower cold filter plugging point of $-11^{\circ} \mathrm{C}$ in comparison with the diesel fuel (Miao \& Wu, 2006).

\section{EXPERIMENTAL DEVELOPMENT}

Life Cycle Assessment (LCA) is a standardized method which allows the integral record, quantification and evaluation of the environmental damages connected with a product, a procedure, or a service in the context of a given question. The ISO 14040/44 methodology for LCA has been used for these purposes (ISO 14040, 2006; ISO 14044, 2006; Stichnothe \& Schuchardt, 2010). The life cycle concept is a cradle to grave systems approach for the study of feedstock, production and use. The concept revolves around the recognition of different stages of production starting from upstream use of energy to cultivation of the feedstock, followed by different processing stages (Baliga \& Powers, 2010). In this study, a cradle to gravewas performed to investigate the environmental sustainability of the integration of the biodiesel production from microalgae dried biomass to distribution. LCA has been chosen as the methodology to evaluate the potential impacts of this study. This methodology is described below:

\section{Goal and Scope Definition}

The overall goal of the study was to compare three scenarios of biodiesel production from microalgae dried biomass applying the LCA technique by means of the "cradle to grave" concept, the analyzed process refers to a different hypothetical systems of extraction of oil (hexane, methanol/chloroform, ethanol/hexane) based on extrapolation from lab-scale and oil esterification transesterification process, each of them being simulated through Aspen Plus ${ }^{\circledR} 7.1$ software. The basis for comparison or the functional unit was defined as $1 \mathrm{~kg}$ of biodiesel. Temporal horizon was 100 years, since this is

Table 2. Comparison of properties from microalgae oil and diesel fuel and ASTM biodiesel standard (Miao \& Wu, 2006).

\begin{tabular}{|lccc|}
\hline \multicolumn{1}{|c|}{ Properties } & Biodiesel from Microalgal Oil & Diesel Fuel & ASTM Biodiesel Standard \\
\hline Density $(\mathrm{kg} / \mathrm{L})$ & 0.864 & 0.838 & $0.86-0.9$ \\
\hline Viscosity $\left(\mathrm{mm}^{2} / \mathrm{s}, \mathrm{CSt}\right.$ at $\left.40^{\circ} \mathrm{C}\right)$ & 5.2 & $1.9-4.1$ & $3.5-5.0$ \\
\hline Flash point $\left({ }^{\circ} \mathrm{C}\right)$ & 115 & 75 & Min 100 \\
\hline Solidifying point $\left({ }^{\circ} \mathrm{C}\right)$ & -12 & -50 to 10 & - \\
\hline Cold filter plugging point $\left({ }^{\circ} \mathrm{C}\right)$ & -11 & $-3.0($ Max -6.7$)$ & Summer max $0 ;$ winter max $<-15$ \\
\hline Acid value $(\mathrm{mg} \mathrm{KOH} / \mathrm{g})$ & 0.374 & Max 0.5 & Max 0.5 \\
\hline Heating value $(\mathrm{MJ} / \mathrm{kg})$ & 41 & $40-45$ & - \\
\hline $\mathrm{H} / \mathrm{C}$ ratio & 1.81 & 1.81 & - \\
\hline
\end{tabular}

*The data about biodiesel from microalgal oil and diesel fuel were taken from published literature as indicated in the text 
the time considered in the impact assessment methodology Environmental Product Declarations (EPD), (ISO 14025, 2006). Location of the system was the Caribe region; consequently, climatic data to determine water loss by evaporation were based on statistics from North Colombia. Besides, neither the construction nor the maintenance of the plant was taken into consideration. Likewise, economic and social factors were not included. Regarding the co-product allocation rules for the extraction and esterification-transesterification stages, the hierarchy proposed by the ISO 14040 (2006) standard was fo-llowed. Furthermore, following the criteria in the quality requirements of the inventory data and according to the rules of LCA, if there are no current flows available, the internationally recognized databases are used in such a way that the values used for these flows respond to controlled processes with regulations more restrictive than the Colombian one, e.g., Renewable Energy Directive (Directive 2009/28/EC).

A complete model of microalgae Chlorella sp. biomass composition was developed through this research for the use in process simulation, based on experimental strain characterization reported, which includes: proteins, aminoacids, carbohydrates, triglycerides and fatty acids. Baseline information was established for the simulation in large scale of three microalgae oil extraction systems: hexane extraction (HE), extraction with methanol/chloroform mixture (MCE) and extraction with ethanol/hexane mixture (EHE). The system boundaries considered in this study start with the oil extraction stage and end at point of distribution as shown in Figure 1.

Assumptions regarding rates of growth, nutrient requirements, yields of lipids, microalgae composition and energy requirements for dry biomass production were based on the results from the literature. Since extraction of algae oil is yet to be practiced on a large scale, little data exist; the analyzed process refers to an on extrapolation from lab-scale studies. The distances over which the raw materials and products would be transported were taken over the Caribe region in Colombia. In order to achieve this, the system was divided into three stages: extraction, biodiesel production and the final process included is transportation and distribution of the biodiesel.

\section{Life Cycle Inventory}

Life Cycle Inventory (LCI) phase involves data collection and modeling of the product system, as well as description and verification of data. This encompasses all data related to environmental and technical quantities for all relevant unit processes within the study boundaries that compose the product system. In this sense, mass and energy balances for the different raw materials and processes in biodiesel production from microalgae dried biomass were performed over each stage.

Inventory data for those energy and material inputs were not available and were obtained from eco-profiles

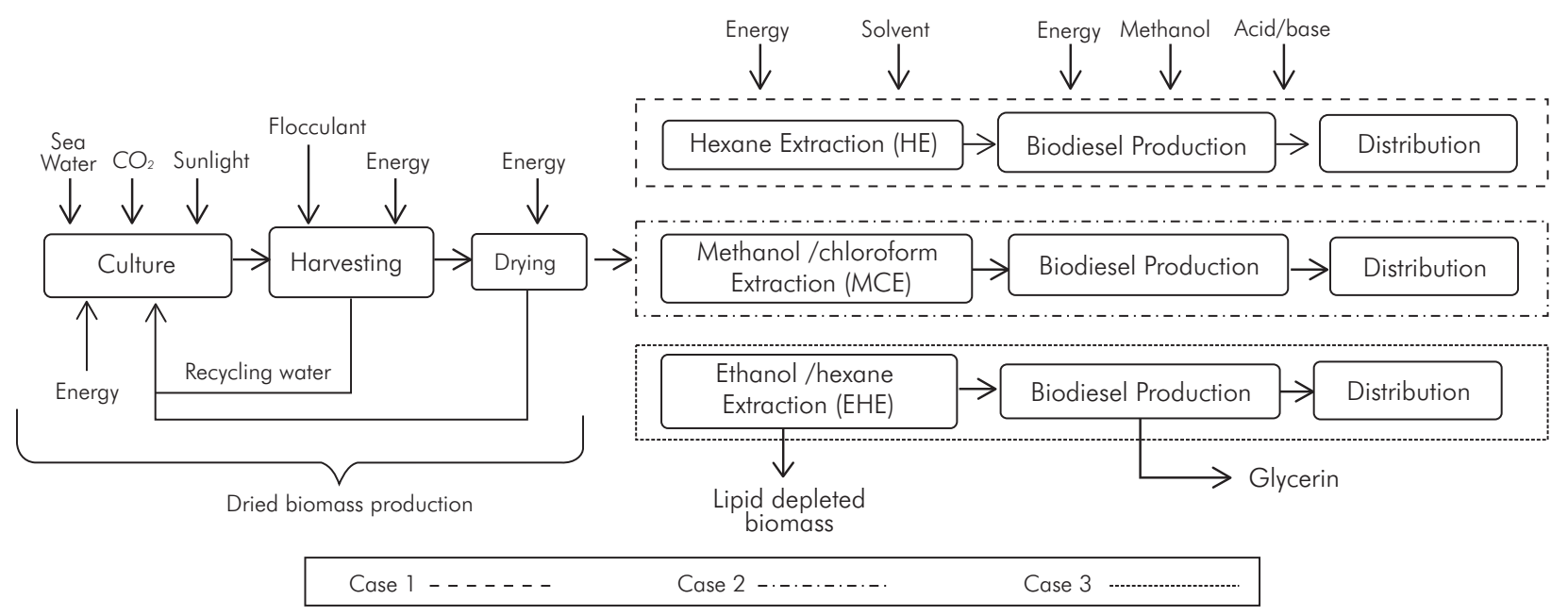

Figure 1. Process chain for biodiesel production from dried biomass production to distribution. 
within SimaPro 7.1 software (Goedkoop et al., 2007) and the ECOINVENT database (Frischknecht et al., 2007). Each case study involves the processes related to the production of raw materials (methanol, chloroform, hexane, ethanol are considered fossil origin), including the production process from obtaining raw materials to the final product manufacture and transportation. Similarly, the electricity and heat production include production and transportation. The energy consumption for each oil extraction method and oil esterification/ transesterification stage were made based on the thermal energy requirements for heat exchangers, reboilers and dryers obtained from each simulation performed. Steam is used for the heating process. The natural gas consumed to provide the required steam energy was calculated based on data reported by Unidad de Planeación Minero Energética of Colombia (Campos, Carmona \& López, 2010).

\section{Composition of Microalgae}

In this study, Chlorella sp. marine species were used because of its potential ease to be used in simulation and availability of experimental information on the physicochemical characterization of the species (carbohydrates and proteins), the free fatty acid profile and unpublished results obtained in lab-scale by authors. Information about the Free Fatty Acid (FFA) compositions was based on the data reported by Petkov and García (2007), and composition was normalized to include FFA. For this standardization, they took a percentage of $30 \%$ oil (Chisti, 2007), which corresponds to a $5.11 \%$ fatty acids and triglycerides (TAG) up to 94.89\% (Ehimen, Sun \& Carrington, 2010). A model of microalgae oil was developed, containing 9 fatty acids and 9 triglycerides. Protein content was of $40 \%$ (Kay, 1991; Phukan, Chutia, Konwar \& Kataki, 2011). For carbohydrates, the literature reports about $25 \%$, including carbohydrates such as cellulose and hemicellulose (Ververis et al., 2007). Finally, the humidity percentage was considered as 5\%. For simplification, each triglyceride is represented as containing three identical components of free fatty acids. In reality, numerous possible combinations exist for the fatty acids comprising each triglyceride (Pokoo-Aikins et al., 2009). As shown in Table 3, the composition of microalgae biomass is more elaborate than the previous studies where microalgae oil is composed only of triolein.

Table 3. Composition of the microalgae Chlorella sp. (\% mass fraction).

\begin{tabular}{|c|c|c|c|c|c|c|c|}
\hline \multicolumn{4}{|c|}{ *Lipids $(30 \%)$} & \multicolumn{2}{|c|}{ ** Proteins } & \multicolumn{2}{|c|}{${ }^{* * *}$ Carbohydrates } \\
\hline Free Fatty Acid (FFA) & 1.53 & Triglycerides (TAG) & 28.47 & Aminoacids & 40.04 & Carbohydrates & 2492 \\
\hline Myristic acid & 0.14 & TAG C 14 & 2.56 & ASP & 4.49 & Cellulose & 7.1 \\
\hline Palmitic acid & 0.38 & TAG C 16-1 & 7.15 & GLU & 5.47 & Lignin & 1.52 \\
\hline Palmitoleic acid & 0.03 & TAG C 16-2 & 0.57 & GLY & 4.35 & Hemicellulose & 16.3 \\
\hline Hexadecadienoic acid & 0.15 & TAG C 16-3 & 2.85 & ALA & 5.4 & & \\
\hline Hexadecatrienoic acid & 0.14 & TAG C 16-4 & 2.56 & VAL & 3.86 & & \\
\hline Stearic acid & 0.01 & TAG C 18-1 & 0.26 & LEU & 4.28 & & \\
\hline Oleic acid & 0.08 & TAG C 18-2 & 1.42 & $\mathrm{PRO}$ & 5.05 & & \\
\hline Linoleic acid & 0.31 & TAG C 18-3 & 5.69 & LYS & 7.15 & & \\
\hline Linolenic acid & 0.29 & TAG C 18-4 & 5.41 & & & & \\
\hline
\end{tabular}

* Petkov \& García, 2007.

** Fowden, 1952.

*** Ververis et al. 2007. 


\section{Dried Biomass Production}

In this scenario it is assumed that a Chlorella sp. microalga is cultivated in an open pond system equipped with an additional $\mathrm{CO}_{2}$ supplier (Kadam, 2002) from external sources to stimulate the growth of the microalgae. It is also assumed that $\mathrm{CO}_{2}$ is fixed from the emissions generated by a power plant flue gas. Chisti (2007) estimated that $1 \mathrm{~kg}$ of dry microalgae biomass can effectively "fix" $1.83 \mathrm{~kg}$ of $\mathrm{CO}_{2}$, the value used in this study. Based on standard design (Borowitzka \& Borowitzka, 1988), the system consist of a channel, with the following dimensions: width $=12 \mathrm{~m}$, length $=500 \mathrm{~m}$ and depth $=0.30 \mathrm{~m}$ (Li et al., 2006). An inlet water stream is needed to replace the water lost to evaporation and an inlet nutrient stream. Sea water is pumped from the nearby coast. The water is agitated by a paddlewheel at a velocity of $0.25 \mathrm{~m} / \mathrm{s}$. The hydraulic power requirement for open pond was estimated. After the growth of algae, itis separated from water by one or two process (Sander \& Murthy, 2010). In this case, a chemical-hydraulic flocculation with aluminum sulfate and filtration was used followed by drying within a thermal dryer. Dewatering and drying of algae is necessary to reduce the water content to $5 \%$ (Lidell, 2001) before the oil extraction process (Baliga \& Powers, 2010).

\section{Oil Extraction}

Presently, there are no large-scale commercial operations that produce and process algae feedstock into biodiesel, so a complete industrial scale algal biodiesel processis not readily available to model. Solvent oil extraction routes included in this study refers to hypothetical systems based on the extrapolations lab-scale in order to obtain the best operating conditions for simulation.

To perform the simulations (through Aspen Plus ${ }^{\circledR}$ 7.1), the first step was to define the components of the mixture and the thermodynamic model used. The thermodynamic models used to simulate the oil extraction and oil esterification/transesterification technologies were NRTL and RK-Soave. Some properties known were introduced, such as: normal boiling point, molecular weight and critical properties; unknown properties were estimated using Universal Functional Group Activity Coefficient (UNIFAC) model and the database Thermo Data Engine (TDE). Thermodynamic properties were calculated based on molecular structures of each compound and the binary interaction coefficients not available in the software library were estimated with the UNIFAC method. The components of the microalgae feedstock were entered manually using the userdefined of Aspen Plus. The structures of each compound were constructed using Chem4-D Demos software and exported to Aspen Plus. Other chemical compounds available in the software's database were used.

\section{Hexane-Based Extraction}

In the first $\mathrm{HE}$ route, this batch microalgae oil extraction method was reported by García, Miranda, González and Kafarov (2010). The solvent hexane was added to create a mixture of hexane to dry biomass under environmental conditions ( $298 \mathrm{~K}, 101325 \mathrm{~Pa})$ in a 20:1 mass ratio (Khoo et al., 2011). Afterwards, mixture is separated through a hydrocyclone (oil extraction) and the extract is filtered to remove fine suspended particles, obtaining a liquid stream rich in solvent and oil and a stream of lipid depleted biomass rich in carbohydrates and protein. The solvent/oil obtained was sent to a decantation and distillation in order to recycle solvent. Liquid components present in lipid depleted biomass stream were separated (solid drying) and sent to the process to increase extraction efficiency.

\section{Methanol/Chloroform Solvent Extraction}

The second extraction route used the mixture methanol/chloroform (MCE), an oil extraction method developed at lab-scale as a modification of the method of Bligh and Dyer for microalgae biomasswith high percent ofash (González, Kafarov \& Guzmán, 2010). Methanol - chloroform - biomass is mixed under environmental conditions in a $6: 12: 1$ mass ratio. The oil extraction process was performed as in the above method. The liquid flow is mixed with water in a $4: 1$ mass ratio to create the phase separation; afterwards, hydrophilic/hydrophobic phases are separated (settling vessel) and each methanol/water and oil/chloroform stream is distillated in order to obtain algae oil, methanol, chloroform and wastewater. Solvents are recycled in order to decrease environmental impacts. Liquid components present in lipid depleted biomass stream are separated (solid drying) and sent to the process. 


\section{Ethanol/Hexane Solvent Extraction}

The third route evaluated is microalgae oil extraction using ethanol-hexane mixture (EHE), a method based in a modification of a lipid extraction method developed by Fajardo et al. (2007) and adapted to local conditions and feedstocks as first step. Biomass was mixed with ethanol to extract crude microalgae oil in 4:1 mass ratio under environmental conditions. The mixture obtained was sent to a separation process (oil extraction) through a hydrocyclone in which biomass is again submitted to the process to increase efficiency. Purification of oil was performed by the formation of a biphasic system generated by the creation of a hydroalcoholic solution of $40 \%$ water $(\mathrm{v} / \mathrm{v})$ and the addition of hexane with a ratio of 1:1 with respect to the alcoholic solution. Finally, the solvents are removed and recycled to the process.

\section{Biodiesel Production (Esterification/transesterifica- tion)}

Biodiesel production from non-edible sources has been extensively studied (Al-Widyan \& Al-Shyoukh, 2002; Dorado et al., 2003). As biodiesel is obtained by means of the transesterification of the TAG's of the oils, there are some cases in which a high content of FFA's makes the oil too acid. This fact makes the basic transesterification no longer the best alternative (Sánchez, Ojeda, El-Halwagi \& Kafarov, 2011). To cope with this, a process has been developed so that before the basic transesterification takes place, there is an esterification of the FFA's with an alcohol in the presence of an acid catalyst. As a result, fatty acid alkyl esters and water are obtained and separated. At this point, an alkali-transesterification of the TAG's with alcohol will take place faster and with less technical difficulties (Marchetti $\&$ Errazu, 2008). The acid value of the microalgae oil was determined by Ehimen et al., (2010) to be 5.11\% (on the basis of the oil weight). In this study, we used this value as shown in the microalgae composition part. First, we performed an acid esterification over alkaline catalysts, followed by a base-catalyzed transesterification (Sánchez et al., 2011).

This reaction of esterification was simulated based on the stoichiometry and assuming fractional conversion of 0.97 mol based on FFA. In this way, the undesired FFA's can be transformed into biodiesel and water in an acid environment (Sánchez et al., 2011). For the reaction, sulfuric acid was used as acid catalyst in a mass ratio of $2.26 \%$ catalyst/oil. In addition, methanol in a molar relation of 6.13:1 alcohol/oil was evaluated. The reaction is carried out at $55^{\circ} \mathrm{C}$ (Marchetti \& Errazu, 2008). Since water and the acid represent an inconvenient in the following stages, a neutralization and decantation step is set just after the esterification reactor. The water is removed together with the recently obtained biodiesel from the mixture. Triglycerides are sent to the transesterification reactor (Sánchez et al., 2011).

$\mathrm{NaOH}$ has been selected as the basic catalyst. A small amount of $1 \%$ catalyst/oil mass ratio was used. Despite safety issues, methanol is preferred on industrial scale because of its high reactivity and low cost. Based on studies of alkali-catalyzed transesterification, the reaction will be carried out at temperature near boilingpoint of alcohol $\left(60^{\circ} \mathrm{C}\right.$ for methanol). To favor the reaction towards the formation of products, an excess of methanol was used (6:1 methanol/oil mol ratio). This molar ratio of $6: 1 \mathrm{alcohol} / \mathrm{oil}$ is also confirmed to be the optimal ratio by numerous studies (Ma \& Hanna, 1999; Tapasvi, Wiesenborn \& Gustafson, 2005; Meher, Sagar \& Naik, 2006; Myint \& El-Halwagi, 2009). In order to obtain biodiesel from microalgae oil, a transesterification reaction was performed in a continuous stirred tank reactor. In this reactor, $97.7 \%$ of the triglycerides entering were transformed into Biodiesel and glycerol. A small amount of unreacted oil, catalyst and alcohol was present in the Biodiesel and glycerol products (Pardo, Sánchez \& Kafarov, 2010).

The products of microalgae oil transesterification stage (biodiesel and glycerol) were cooled to a temperature of $30^{\circ} \mathrm{C}$. A decanter (Biodiesel/Glycerol separation) was used in order to remove the glycerol rich phase. FAME and glycerol are cooled down and separated at a lower temperature and at atmospheric pressure because of their immiscibility and specific gravity difference. The glycerol is drawn off the bottom of the settling vessel (Pokoo-Aikins, Nadim, El-Halwagi \& Mahalec, 2009). Both Biodiesel rich phase and glycerol rich phase contains basic catalyst that must be neutralized with a strong acid to avoid the formation of soaps and emulsions (Zhang, Dubé, McLean \& Kates, 2003). The Biodiesel obtained after neutralization was sent to a distillation 
tower in order to remove methanol. After glycerol and methanol removal, the Biodiesel stream was sent to washing stage in order to remove impurities. A decanter was then used to separate water from biodiesel. Finally, biodiesel was sent to a distillation tower in order to remove excess water and then transported $236 \mathrm{~km}$. The Biodiesel obtained from the microalgae satisfies most of the ASTM specifications.

\section{Life Cycle Impact Assessment and Interpretation}

According to the United Nations Environment Programme (UNEP, 2003), life cycle impact assessment allows to aggregate all the inventory data in order to quantify the environmental load. In this study, potential environmental impacts are assessed using Simapro7.1 software. The EDP 2007 methodology was selected because it was developed in concert with the ISO14040 (2006) and ISO 14044 (2006), being a mid-point method that allows fair comparison of processes based on their environmental performance. The impact categories considered were: Global Warming Potential (GWP), acidification (AC), eutrophication (EU), photochemical oxidation (PO), ozone layer depletion (ODP) and non-renewable fossil (nRE-fossil)

\section{RESULTS}

In this work, results are presented in two ways. On one hand, results of the inventory analysis show the incidence of each input/output stream in the impact categories. On the other hand, results of impact assessment show the impact variation for each studied case.

\section{Inventory Results of LCA}

As it was pointed out earlier, the inventory data used in this study was mainly from databases and the literature. In the same way, available data from the Simapro tool was used, especially for the most common processes such as transportation, fuel and chemicals. Tables 4, 5 and 6 show a compilation of the mass and energy flows of each extraction systems. They also present the biodiesel production process flows, taking into account that the functional unit is $1 \mathrm{~kg}$ of biodiesel.
Table 4. Mass and energy flow for biomass production. Base $1 \mathrm{~kg}$ of biodiesel.

\begin{tabular}{|lcc|}
\hline \multicolumn{1}{|c}{ Dried Biomass Production } & Value & Units \\
\hline Flow input $\mathrm{CO}_{2}$ & 6.45 & $\mathrm{~kg}$ \\
\hline Flow input Urea $(\mathrm{N})$ & 0.05 & $\mathrm{~kg}$ \\
\hline Flow input sea water & 62.65 & $\mathrm{~kg}$ \\
\hline Flow input $\mathrm{Al}_{2}\left(\mathrm{SO}_{4}\right)_{3}$ & 0.190 & $\mathrm{~kg}$ \\
\hline Heat consumption & 92.71 & $\mathrm{MJ}$ \\
\hline Electricity consumption & 7.32 & $\mathrm{~kW} \cdot \mathrm{h}$ \\
\hline Flow out dried biomass & 3.09 & $\mathrm{~kg}$ \\
\hline Emissions to air & & \\
\hline Water & 62.50 & $\mathrm{~kg}$ \\
\hline $\mathrm{N}_{2} \mathrm{O}$ & $5.764 \mathrm{E}-07$ & $\mathrm{~kg}$ \\
\hline Emissions to water & & \\
\hline Salts, unspecified & 83.59 & $\mathrm{~kg}$ \\
\hline Final waste residue & & $\mathrm{kg}$ \\
\hline Solid losses & $3.50 \mathrm{E}-03$ & \\
\hline
\end{tabular}

Table 5. Mass and energy flow for extraction stage. Base $1 \mathrm{~kg}$ of biodiesel.

\begin{tabular}{|lcc|cc|}
\hline \multicolumn{1}{|c}{ Extraction Stage } & HE & EHE & MCE & Units \\
\hline Dried input biomass & 3.42 & 3.43 & 3.52 & $\mathrm{~kg}$ \\
\hline Flow input hexane & 0.0031 & - & - & $\mathrm{kg}$ \\
\hline Flow input ethanol & - & 6.91 & - & $\mathrm{kg}$ \\
\hline Flow input hexane & - & 0.001 & - & $\mathrm{kg}$ \\
\hline Flow input methanol & - & - & 4.74 & $\mathrm{~kg}$ \\
\hline Flow input chloroform & - & - & 0.001 & $\mathrm{~kg}$ \\
\hline Flow input water & - & 29.11 & 13.16 & $\mathrm{~kg}$ \\
\hline Heat consumption & 80.12 & 119.3 & 88.78 & $\mathrm{MJ}$ \\
\hline Electricity consumption & 0.009 & 0.002 & 0.005 & $\mathrm{kWh}$ \\
\hline Flow out dried biomass (coproduct) & 2.22 & 2.23 & 2.29 & $\mathrm{~kg}$ \\
\hline Flow out microalgae oil & 1.028 & 1.028 & 1.028 & $\mathrm{~kg}$ \\
\hline Emissions to water & & & & \\
\hline Wastewater & 0.173 & 36.2 & 18.11 & $\mathrm{~kg}$ \\
\hline
\end{tabular}


Table 6. Mass and energy flow for $1 \mathrm{~kg}$ of biodiesel.

\begin{tabular}{|lcc|}
\hline \multicolumn{1}{|c}{ Biodiesel Production } & Value & Units \\
\hline Flow input microalgae oil & 1.028 & $\mathrm{~kg}$ \\
\hline Flow input methanol & 0.15 & $\mathrm{~kg}$ \\
\hline Flow input $\mathrm{NaOH}$ & 0.011 & $\mathrm{~kg}$ \\
\hline Flow input $\mathrm{H}_{2} \mathrm{SO}_{4}$ & 0.013 & $\mathrm{~kg}$ \\
\hline Flow input water & 0.088 & $\mathrm{~kg}$ \\
\hline Heat consumption & 1.87 & $\mathrm{MJ}$ \\
\hline Electricity consumption & 0.003 & $\mathrm{~kW} \cdot \mathrm{h}$ \\
\hline Flow out glycerin (coproduct) & 0.134 & $\mathrm{~kg}$ \\
\hline Emissions to water & & \\
\hline Wastewater & 0.152 & $\mathrm{~kg}$ \\
\hline
\end{tabular}

The emissions associated with the inventory results of the different extraction systems studied are shown in Figure 2. They were grouped by categories of impact, and Figure 2a shows the emissions of $\mathrm{CO}_{2}, \mathrm{CH}_{4}, \mathrm{~N}_{2} \mathrm{O}, \mathrm{CO}$ included in the category of GWP. Figures $2 b, c, d$ and $e$ summarize the most common substance in the categories of eutrophication, acidification, photochemical oxidation and ozone layer depletion.
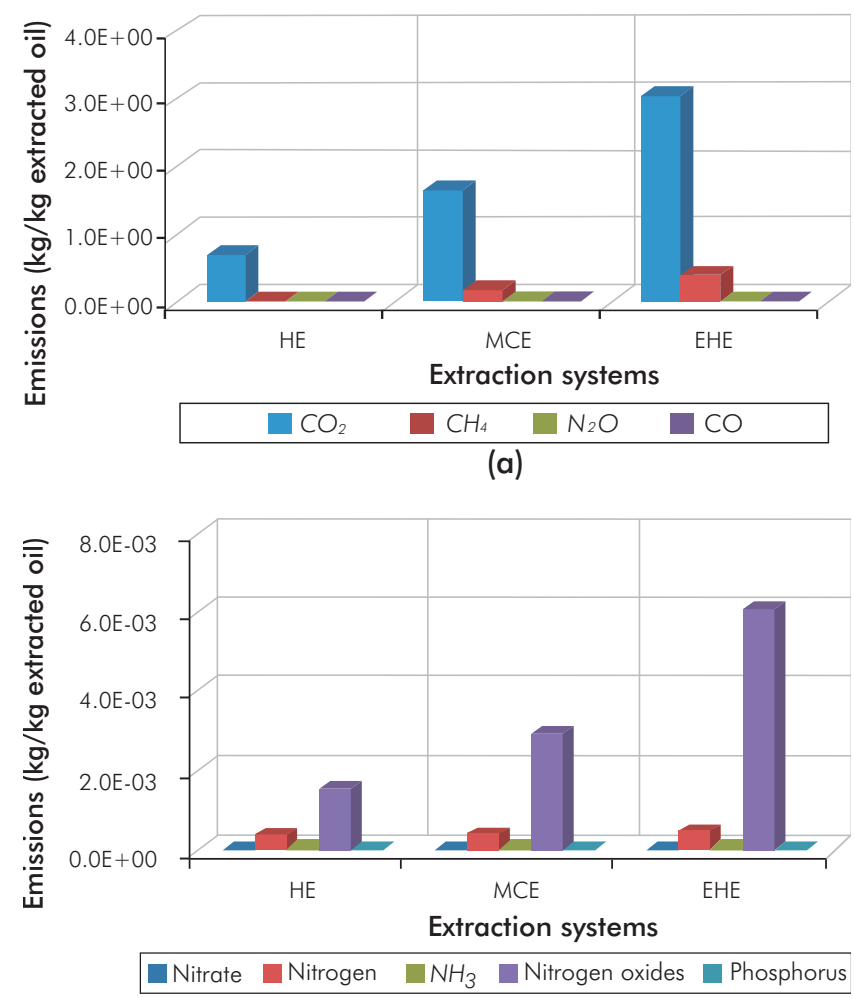

(b)

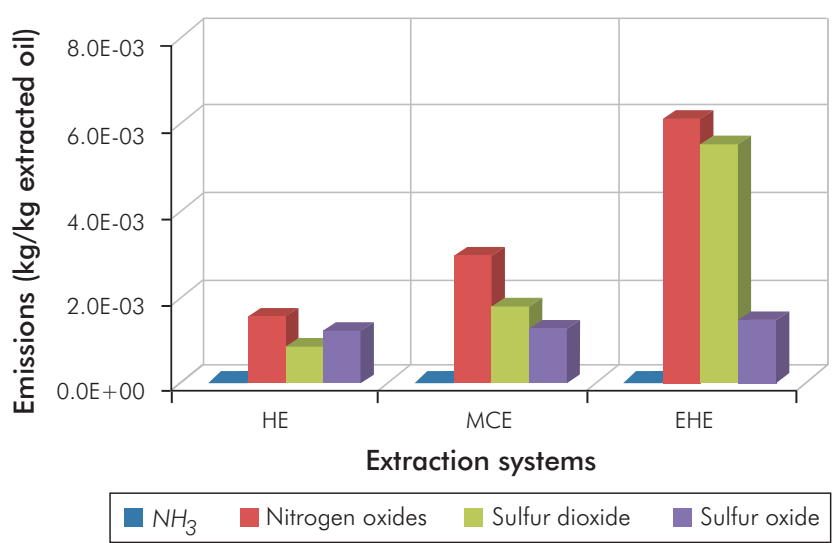

(c)

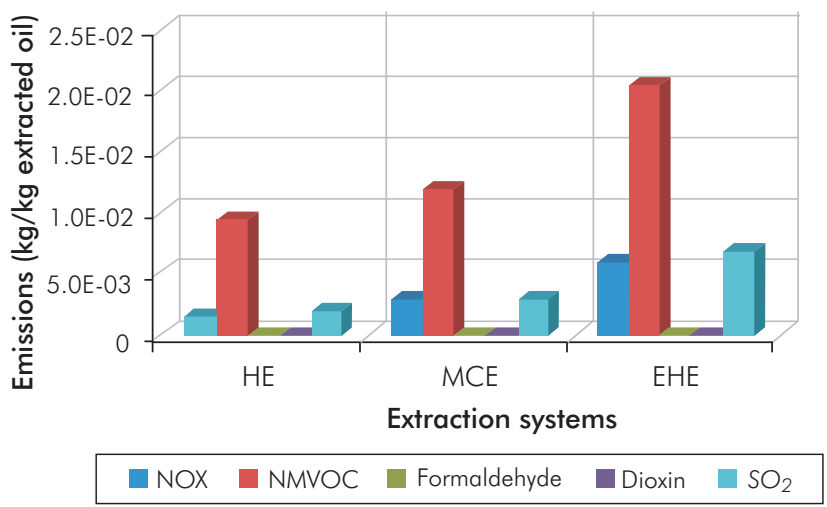

(d)

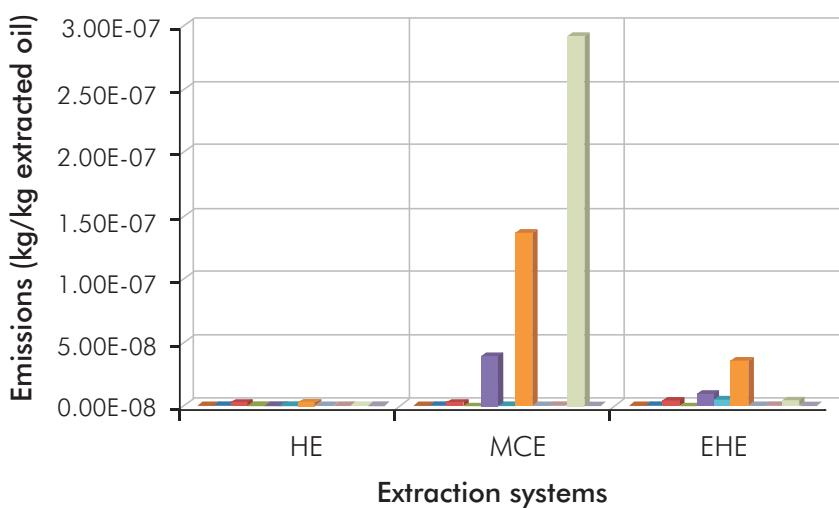

\begin{tabular}{|lcc|}
\hline Ethane, HCFC-140 & Ethane CFC-113 & Ethane, CFC-114 \\
Methane, Halon 1001 & Methane, Halon 1211 & Methane, Halon 1301 \\
Methane, HCFC-22 & Methane, CFC-12 & Methane, R-40 \\
Methane, CFC-10 & Methane, CFC-11 & \\
\hline
\end{tabular}

(e)

Figure 2. Contribution to the inventory of emissions of the three oil extraction systems studied in each impact category. (a) Global-warming potential (GWP100). (b) Eutrophication. (c) Acidification. (d) Photochemical oxidation. (e) Ozone layer depletion (ODP). 
Energy requirements for each extraction system composed oil extraction (biomass/oil separation), dried solids (depleted lipid biomass) and solvent recovery as shown in Figure 3. It can be observed that the biggest energy consumed for each case comes from microalgae extraction stage, being EHE the one presenting the highest energy requirement.

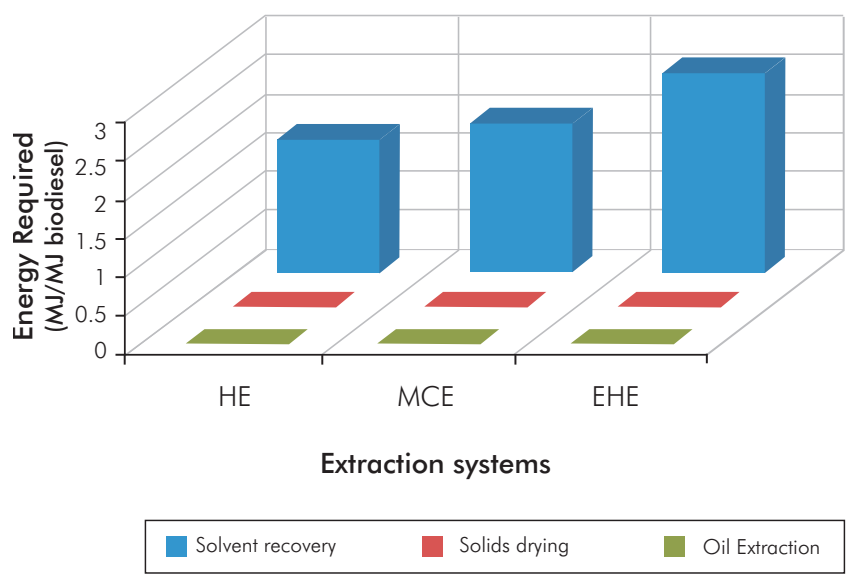

Figure 3. Fossil energy use (fossil energy MJ-eq/MJ biodiesel).

\section{Energy Allocation to Biodiesel}

The two primary co-products of the biodiesel production from dry microalgae biomass are lipid depleted biomass (generated from the extraction stage) and glycerin (generated from esterification-transesterification stage). The following indicates the energy allocation (\%) carried out for each of the cases within the study. For every kilogram of biodiesel, $2.22 \mathrm{~kg}$ of lipid are produced in case 1;2.29 kg of lipid are produced in case 2 and $2.23 \mathrm{~kg}$ of lipid are produced in case 3. Additionally, $0.134 \mathrm{~kg}$ of glycerin is produced in all three cases. The Lower Heating Value (LHV) of glycerin was assumed to be $16 \mathrm{MJ} / \mathrm{kg}$ glycerin and the LHV of lipid depleted biomass was calculated to be $14.54 \mathrm{MJ} / \mathrm{kg}$ lipid depleted biomass. The energy allocation is calculated as $54.35 \%$ for biodiesel in case $1,53.68 \%$ for biodiesel in case 2 and $54.25 \%$ for biodiesel in case 3 .

\section{Results of Potential Environmental Impacts}

This section shows the potential impact evaluation of the stages involving the Life Cycle of the whole biodiesel production. Figure 4 a shows that for case 1 the most influential impact category is non renewable fossil. In the same way, the most influential impact category in case 2 and case 3 -NRE-fossil- is shown in Figure $4 \mathrm{~b}$ and $\mathrm{c}$.

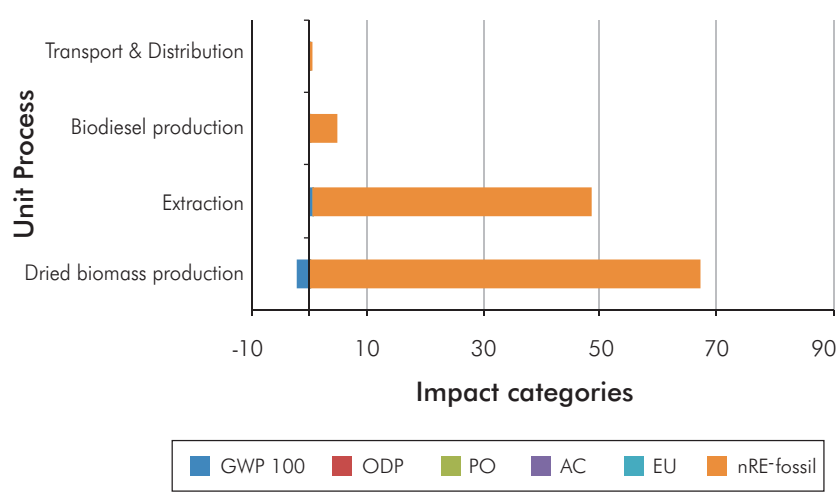

(a)

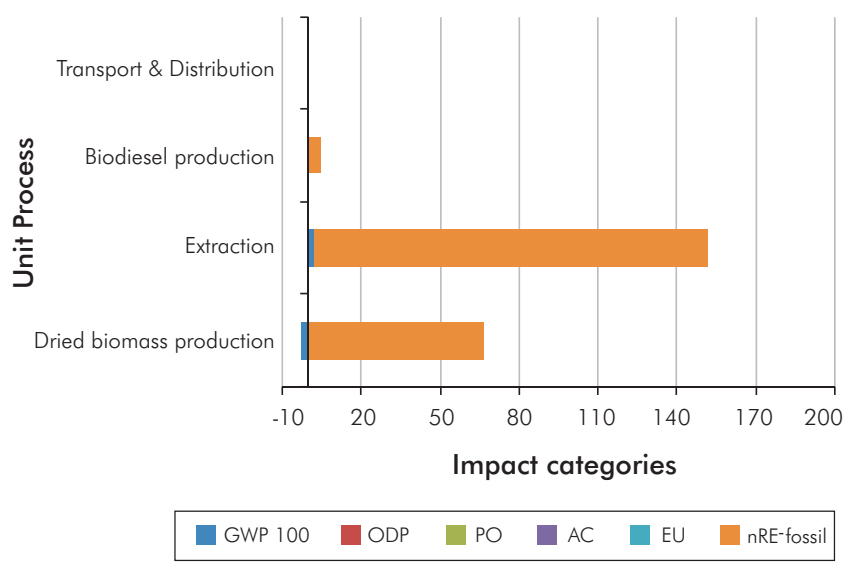

(b)

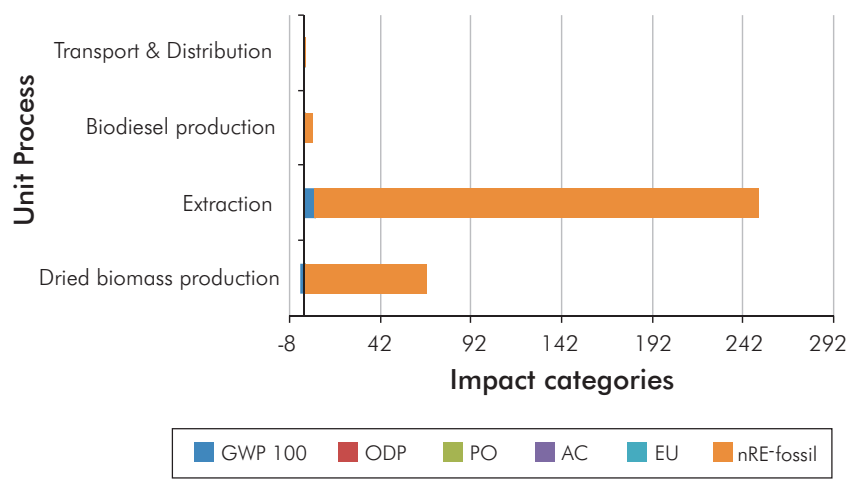

(c)

Figure 4. Potential environmental impact for: (a) Case 1 (HE). (b) Case 2 (MCE). (c) Case 3 (EHE). 
In order to assess the theoretical compliance with sustainability criteria proposed in European Directive 2009/28/EC, Non-renewable Energy Consumption and Global Warming Potential associated with the three cases of biodiesel production were compared with $1 \mathrm{MJ}$ of conventional fossil diesel (Figure 5). Results indicate that case 1 has lower non-renewable energy consumption and GWP than case 2 and case 3.

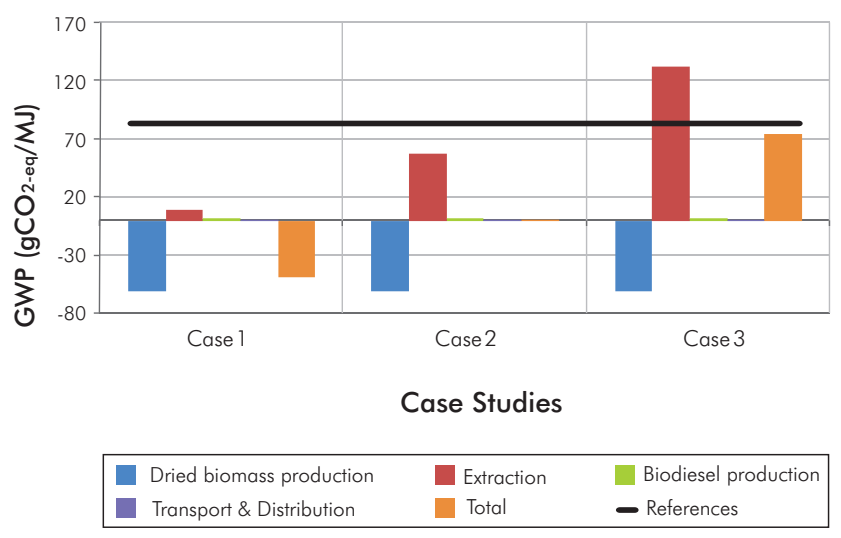

Figure 5. Results comparing three cases studies. Greenhouse gases emissions ( $\mathrm{g} \mathrm{CO}_{2}$-eq/ MJ biodiesel).

\section{RESULTS ANALYSIS}

\section{Inventory Results of $L C A$}

According to Figure 2, case 3 presents the higher value for almost all studied emissions. $\mathrm{CO}_{2}$ emissions (Figure 2a) are mainly due to the use of ethanol, which represents $74.68 \%$ of contribution. These emissions are normally derived from fossil fuels. In this case, use of natural gas for oil extraction contributes with $6.28 \%$ and with $18.77 \%$ for dried biomass production. Furthermore, this scenario shows significant emissions of nitrogen oxides (Figure 2b, c), sulfur dioxide (Figure 2c) and non-methane volatile organic compounds of unspecified origin (NMVOC) (Figure 2d) by the ethanol, natural gas and dried biomass production. In contrast, from Figure $2 \mathrm{e}$ it can be observed that the biggest pollutant emissions correspond to case 2 , which are mainly due to methanol and chloroform usecoming from the extraction system used. In this case, methaneHalon 1211 and methane- HCFC-22 represent 96.93\% and $96.72 \%$ of the methanol used. Similarly, Methane CFC-10 represents $99.64 \%$ of the chloroform used.

Consistent with energy analysis, it is possible to notice from Figure 3 that the biggest energy consumed for each case comes from microalgae extraction stage, being EHE the one with the highest energy requirement: 7.28 MJ per MJ biodiesel. Comparing the oil extraction system, it can be observed that HE (case 1) contains the lowest energy requirement with a value of 1.77 MJ/MJ biodiesel. In the same way, results indicate that the energy requirements of extraction processes (oil extraction, solids drying and solvent recovery) in each case are mainly due to solvent recovery. This consumption is specifically due to the amount of thermal energy.

Based on the functional unit of $1 \mathrm{~kg}$ of biodiesel and assuming a heating value of $41 \mathrm{MJ}$ per $\mathrm{kg}$ biodiesel (Khoo et al., 2011), the total energy demand for each case is presented as follows. Case 1: $1.91 \mathrm{MJ}$ with $93 \%$ from oil extraction, $6.8 \%$ from biodiesel production and $0.2 \%$ from distribution. Case 2: 4.48 MJ with 97\% from oil extraction, 2.9\% from biodiesel production and $0.1 \%$ from distribution. Case $3: 7.28 \mathrm{MJ}$ with $98.2 \%$ from oil extraction, $1.8 \%$ from biodiesel production and $0.1 \%$ from distribution.

\section{Results of Potential Environmental Impacts}

In terms of impact, Figures 4 show that the most relevant impact category is nRE-fossil, mainly due to the significant consumption of natural gas as fuel for heat generation. In case 1 , the most important contributors are dried biomass production, which represent approximtely $55.9 \%$, and oil extraction stage with $40 \%$ of contribution. The greater consumption of heat in the process of dried biomass production is generated by the biomass drying stage prior to oil extraction stage. This behavior is contrasting for cases 2 and 3, where oil extraction process show a higher contribution than dried biomass production. In case 2 , oil extraction contributes with $68 \%$ in front of $30 \%$ for dried biomass. In case 3 , this percent increase to $77 \%$.

For all scenarios, transesterication stage and distribution present unrelevant contributions. European Directive 2009/28/EC establishes a common framework 
for the promotion of energy from renewable sources. In this sense, Article 17 refers to the sustainability criteria for biofuels and bioliquids, highlighting that the GHG emission saving from the use of biofuels and bioliquids shall be at least $35 \%$. For biofuels, for the purposes of the calculation referred to GHG savings, the fossil fuel comparator emissions shall be $83.8 \mathrm{~g} \mathrm{CO}_{2}$ eq/MJ. Figure 5 illustrates the GHG savings for three biofuels production cases using the previous default value for conventional diesel.

Results show a significative reduction of GHG for case $1(156 \%)$, which can be explained due to immense capture of $\mathrm{CO}_{2}$ during biomass production stage. This reduction decreased for cases $2(99.46 \%)$ and $3(14.68)$ respectivaly.

\section{CONCLUSIONS}

- This study allows proving-by means of three different cases- the relevance of energy consumption in the microalgae biodiesel production. Furthermore, the study showed hotspots for each case, being the EHE method the one presenting the highest energy requirement. Comparing the oil extraction system, it can be observed that HE (case 1) showed the lowest energy requirement compared with the other two cases. In the same way, results indicate that the energy requirements of extraction processes (oil extraction, solids drying and solvent recovery) in each case are mainly due to solvent recovery.

- Consume of fossil fuel, in terms of natural gas for heat generation, is the most important vector in impact quatification. In the best scenario (case 1), it contributes with more than $50 \%$.

- In this sense, it is necessary to find alternatives to decrease energy consumption. On one hand, these alternatives can be related to technical improvements on the oil extraction step in order to increase efficiency. On the other hand, the options can be related to changes in energy sources, by use of biomass as fuel for heat generation.
- For GHG emissions, comparing with European sustainability criteria, two of three scenarios showed hypothetical reduction. Case 1 presents the most important reduction, near to $156 \%$ respect to fossil reference. In the other two scenarios, the reduction decreases because of the higher energy consumption. Case 2 presents a reduction of approximately $99 \%$, and case 3 presents reduction of $14 \%$. In terms of impact, for all scenarios, transesterication stage and distribution present unrelevant contributions.

- Regarding the differences among the three scenarios of biodiesel production analyzed, the HE system presents an excellent environmental performance in all categories discussed, except for ozone layer depletion (ODP).

\section{ACKNOWLEDGEMENTS}

The authors thank the Departamento Administrativo de Ciencia, Tecnología e Innovación COLCIENCIAS; the Ministerio de Agricultura y Desarrollo Rural, Colombia and the Iberoamerican Science \& Technology Development Programme (CYTED).

\section{REFERENCES}

Al-Widyan, M. I. \& Al-Shyoukh, A. O. (2002). Experimental evaluation of the transesterification of waste palm oil into biodiesel. Biores. Technol., 85(3), 253-256.

Antolín, G., Tinaut, F. V., Briceño, Y., Castaño, V., Pérez, C. \& Ramírez A. I. (2002). Optimisation of biodiesel production by sunflower oil transesterification. Biores. Technol., 83(2), 111-114.

Baliga, R. \& Powers, S. (2010). Sustainable algae biodiesel production in cold climates. Int. J. Chem. Eng., 2010: 1-13.

Bligh, E. J. \& Dyer, W. J. (1959). A rapid method of total lipid extraction and purification. Can. J. Biochem. Physiol., 37(8), 911-917.

Borowitzka, M. A. \& Borowitzka, L. J. (1988). Dunaliella. In: Borowitzka, M. A. \& Borowitzka, L. J. Microalgal 
Biotechnol. Cambridge: Cambridge University Press. 27-58.

Campos, A. J., Carmona, G. \& López, F. D. (2010). Casos URE exitosos en Colombia: Reducción de los costos energéticos en sistemas de generación de vapor. Informe Técnico, Unidad de Planeación Minero Energética (UPME), Instituto Colombiano para el Desarrollo de la Ciencia y la Tecnología "Francisco José de Caldas" (COLCIENCIAS).

Cherubini, F. (2010). The biorefinery concept: Using biomass instead of oil for producing energy and chemicals. Energy Convers. Manage., 51(7), 1412-1421.

Chisti, Y. (2007). Biodiesel from microalgae. Biotechnol. Advanc., 25(3), 294-306.

Directive 2009/28/EC of the European Parliament and the Council of 23 April (2009) on the promotion of the use of energy from renewable sources and amending and subsequently repealing Directives 2001/77/EC and 2003/30/ EC, 05/06/2009, Official J. Eur. Union.

Dorado, M. P., Ballesteros, E., Arnal, J. M., Gómez, J. \& López, F. J. (2003). Exhaust emissions from a diesel engine fuelled with transesterified waste olive oil. Fuel, 82(11), 1311-1315.

Ehimen, E. A., Sun, Z. F. \& Carrington, C. G. (2010). Variables affecting the in situ transesterification of microalgae lipids. Fuel, 89(3), 677-684.

Fajardo, A. R., Cerdán, L. E., Medina, A. R., Fernandez, F. G. A., Moreno P. A. G. \& Grima E. M. (2007). Lipid extraction from the microalga Phaeodactylum tricornutum. Eur. J. Lipid Sci. Technol., 109(2), 120-126.

Fowden, L. (1952). The Composition of the bulk proteins of Chlorella. Biochem. J., 50(3), 355-358.

Frischknecht, R., Jungbluth, N., Althaus, H., Doka, G., Heck, T., Hellweg, S., Hischier, R., Nemeck, T., Rebitzer, G., Spielmann, M. \& Wernet, G. (2007). Overview and methodology. Dübendorf: Rolf and Niels.

Fuls, J., Hawkins, C. S. \& Hugo, J. C. (1984). Tractor engine performance on sunflower oil fuel. J. Agri. Eng. Res., 30: 29-35.

Gao, C. F., Zhai, Y., Ding, Y. \& Wu, Q. Y. (2010). Application of sweet sorghum for biodiesel production by heterotro- phic microalga Chlorella protothecoides. Appl. Energy, 87(3), 756-761.

García, J., Miranda, J., González, A. D. \& Kafarov, V. (2010). Comparison of microalgae oil extraction methods for biodiesel production. IV International Congress of Biofuels Science and Technology CIBSCOL, Bucaramanga, Colombia.

Goedkoop, M., De Schryver, A., Oele, M., Durksz, S. \& Roest, D. (2007). Introduction to LCA with SimaPro 7.1. California: Pré Consultants.

González, A. D., Kafarov, V. \& Guzmán, A. (2010). Comparison of microalgae oil extraction methods for third generation biofuel production. 19th International Congress of Chemical and Process Engineering CHISA, Prague, Czech Republic.

González-Delgado, A. \& Kafarov, V. (2011). Microalgae based biorefinery: Issues to consider. $C T \& F-C i e n c i a$ Tecnología y Futuro, 4(4), 5-21.

GuanHua, H., Feng, C., Dong, W., XueWu, Z. \& Gu, C. (2010). Biodiesel production by microalgalbiotechnology. Appl. Energ., 87(1), 38-46.

Halim, R., Gladman, B., Danquah, M. K. \& Webley, P. A. (2011). Oil extraction from microalgae for biodiesel production. Bioresour. Technol., 102(1),178-185.

Huntley, M. \& Redalje, D. (2007). $\mathrm{CO}_{2}$ Mitigation and renewable oil from photosynthetic microbes: A new appraisal. Mitigat. Adapt. Strat. Global Change, 12(4), 573-608.

ISO 14025. (2006). Environmental labels and declarations. Type III environmental declarations. Principles and procedures. International Organization for Standarization, Switzerland.

ISO 14040. (2006). Environmental management-life cycle assessment-principles and framework. First edition, International Organization for Standarization, Switzerland.

ISO 14044. (2006). Environmental management-life cycle assessment-requirements and guidelines, First edition, International Organization for Standarization, Switzerland.

Kadam, K. L. (2002). Environmental implications of power generation via coal-microalgae cofiring. Energy, 27(10), 905-922. 
Kay, R. A. (1991). Microalgae as food and supplement. Crit. Rev. Food Sci. Nutr., 30(6), 555-573.

Khoo, H. H., Sharratt, P. N., Das, P., Balasubramanian, R. K., Naraharisetti, P. K. \& Shaik, S. (2011). Life cycle energy and $\mathrm{CO}_{2}$ analysis of microalgae-to-biodiesel: Preliminary results and comparisons. Bioresour. Technol., 102(10), 5800-5807.

Lang, X., Dalai, K., Bakhshi, N., Reaney, J. \& Hertz, P. (2001). Preparation and characterization of bio-diesels from various bio-oils. Bioresour. Technol., 80(1), 53-62.

Li, Y., Horsman, M., Wu, N., Lan, C. \& Dubois-Calero, N. (2008). Biofuels from microalgae. Biotechnol. Prog., 24(4), 815-820.

Li, Y., Markley, B., Mohan, A. R., Rodriguez-Santiago, V., Thompson, D. \& Niekerk, D. V. (2006). Utilization of carbon dioxide from coal-fired power plant for the production of value-added products. Design Engineering of Energy and Geo-Environmental Systems Course (EGEE 580). Internal document for a course. College of Earth and Mineral Science.

Lidell, J. M. (2001). U.S. Patent No. 6.180.376. Extraction of triglycerides from microorganisms. London.

Ma, F. R. \& Hanna, M.A. (1999). Biodiesel production: a review. Bioresour. Technol., 70(1), 1-15.

Marchetti, J. M. \& Errazu, A. F. (2008). Esterification of free fatty acids using sulfuric acids catalyst in the presence of triglycerides. Biomass Bioenergy, 32(9), 892-895.

Meher, L. C., Sagar, D. V. \& Naik, S. N. (2006). Technical aspects of biodiesel production by transesterification-a review. Renew. Sustain. Energ. Rev., 10(3), 248-268.

Miao, X. \& Wu, Q. (2006). Biodiesel production from heterotrophic microalgaloil. Bioresour. Technol., 97(6), 841-846.

Myint, L. L. \& El-Halwagi, M. M. (2009). Process analysis and optimization of biodiesel production from soybean oil. J. Clean Tech. Environ. Policy, 11(3), 263-276.

Pardo, Y., Sánchez, E. \& Kafarov, V. (2010). Life cycle assessment of third generation biofuels production. Chem. Eng. Transact., 21(1), 1177-1182.

Petkov, G. \& García, G. (2007). ¿Which are fatty acids of the green alga Chlorella?. Biochem. Syst. Ecol, 35(5), 281-285.
Phukan, M. M., Chutia, R. S., Konwar, B. K. \& Kataki, R. (2011). Microalgae Chlorella as a potential bioenergy feedstock. Appl. Energ., 88(10), 3307-3312.

Pokoo-Aikins, G., Nadim, A., El-Halwagi, M. \& Mahalec, V. (2009). Design and analysis of biodiesel production from algae grown through carbon sequestration. Clean. Techn. Environ. Policy, 12(3), 239-254.

Sánchez, E., Ojeda, K., El-Halwagi, M. \& Kafarov, V. (2011). Biodiesel from microalgae oil production in two sequential esterification/transesterification rea.tors: Pinch analysis of heatintegration. Chem. Eng. J., 176177: 211-216.

Sander, K. \& Murthy, G. (2010). Life cycle analysis of algae biodiesel. Int. J. Life Cycle Ass., 15(7), 704-714.

Stichnothe, H. \& Schuchardt, F. (2010). Comparison of different treatment options for palm oil production waste on a life cycle basis. Int. J. Life Cycle Ass., 15(9), 907-915.

Tapasvi, D., Wiesenborn, D. \& Gustafson, C. (2005). Process model for biodiesel production from various feedstocks. Am. Soc. Agric. Eng., 48(6), 2215-2221.

UNEP, (2003). Evaluation of environmental impacts in life cycle assessment. Paris: US-EPA.

Ververis, C., Georghiou, K., Danielidis, D., Hatzinikolaou, D. G., Santas, P., Santas, R. \& Corleti, V. (2007). Cellulose-hemicellulose, lignin and ash content of some organic materials and their suitability for use as paper supplements. Bioresour. Technol., 98(2), 296-301.

Vicente, G., Martínez, M. \& Aracil, J. (2004). Integrated biodiesel production: a comparison of different homogeneous catalysts systems. Bioresour. Technol., 92(3), 297-305.

Zhang, Y, Dubé, M. A, McLean, D. D. \& Kates, M. (2003). Biodiesel production from waste cooking oil: 2. Economic assessment and sensitivity analysis. Bioresour. Technol., 90(3), 229-240.

\section{AUTHORS}

\section{Yeniffer Pardo-Cárdenas}

Affiliation: Universidad Industrial de Santander. Ing. Química, Universidad Industrial de Santander. e-mail: mailto:yenniferpardo@gmail.com 


\section{Israel Herrera-Orozco}

Affiliation: Centro de Investigaciones Energéticas, Medio Ambientales y Tecnológicas, Madrid, España. Ing. Química, Universidad Industrial de Santander. Ing. Ambiental, Universidad Industrial de Santander. D.E.A. Ingeniería Química y de Procesos,

Universitat Rovira $i$ Virgili.

$\mathrm{Ph}$. D. Ingeniería Química y de Procesos, Universitat Rovira i Virgili.

e-mail: israel.herrera@ciemat.es

\section{Ángel-Darío González-Delgado}

Affiliation: Universidad Industrial de Santander, Universidad de San Buenaventura.

Ing. Química, Universidad Industrial de Santander. e-mail: andagon@gmail.com

\section{Viatcheslav Kafarov}

Affiliation: Universidad Industrial de Santander. Cibernética en Procesos de Ing. Química, Universidad Rusa de Tecnología Química D I Mendeleyev.

M. Sc. Matemática Aplicada, Universidad Estatal Lomonosov de Moscú.

$\mathrm{Ph}$. D. Ingenier Habil, Martin Luther Universität Halle Wittenberg. $\mathrm{Ph}$. D. Ciencias Técnicas, Universidad Rusa de Tecnología Química D I Mendeleyev.

e-mail:kafarov@uis.edu.co 